\title{
Hegel, Human Rights, and Political Membership ${ }^{1}$
}

\author{
Andrew Buchwalter
}

\begin{abstract}
This paper examines Hegel's view of the relationship of human rights and political membership. Attention is accorded the concept of a right to have rights, one famously thematized by Hannah Arendt but articulated already earlier by Hegel. The discussion has five parts. Part One considers how for Hegel a notion of political membership is entailed by the concept of right itself. Part Two examines the place occupied by modern civil society in a realised account of human rights. Part Three considers the challenges posed to realised right by the phenomenon of modern poverty and the experience of 'rightlessness' it occasions. Part Four details how Hegel's conception of the corporation addresses the phenomenon of rightlessness, taking into account his uniquely reflexive understanding of a right to have rights and its contribution to the project of the Philosophy of Right. The concluding section briefly compares Hegel's conception of membership rights to Arendt's.
\end{abstract}

In recent years much attention has been accorded an account of human rights as 'the right to have rights'. This view is distinctive as it rejects essentialist, ahistorical notions of human rights in favour of those conceptually tied to membership in a legal-political community. The thinker most clearly associated with this understanding of human rights is Hannah Arendt, whose 1951 The Origins of Totalitarianism gave it near canonical articulation. Responding to the 'rightlessness' experienced by stateless groups and individuals during and after World War II, she asserted that human rights have real meaning not with regard to abstract invocations of human dignity, but only to the degree that subjects are members of an organized community able to acknowledge their standing claims. Arendt's view is particularly distinctive, as she claims that such membership is required not just for citizenship but personhood itself.

Yet if current discussion of 'the right to have rights' derives from the work of Arendt, she herself was not the first to formulate this concept. An earlier articulation is found in the work of Hegel, and in particular in lecture versions of 


\section{Andrew Buchwalter}

the Philosophy of Right (VPRHe: 127). ${ }^{2}$ In these works, Hegel not only employs the same locution, he does so in ways that anticipates Arendt's particular usage. In keeping with his conception of realised freedom, Hegel maintains as well that implicit in the idea of rights is the right to membership in a political community that recognises, enforces and facilitates those rights. Also with Arendt, he formulates this idea in response to the 'rightlessness' experienced by modern social individuals. For Hegel, the notion of a right to have rights is articulated at least in part in recognition that certain individuals in modern society are deprived of the rights needed not only for citizenship but personhood itself.

In what follows I detail Hegel's view of the relationship of human rights and political membership, focusing on his distinctive understanding of a right to have rights. My discussion is divided into five parts. First I consider how for Hegel a notion of political membership is entailed by the concept of right itself, focusing on the intersubjective conception of personhood that undergirds his 'commandment of right', the definition of right as itself 'the existence of the free will', and his reception of the natural law tradition. Second, I address the central place occupied by modern commercial society—for Hegel, civil society (bürgerliche Gesellschaft) —in a realised account of human rights as well as the determination of what counts as rights. Here I focus on Hegel's treatment of 'negative' liberty rights, 'positive' welfare rights, political rights, as well as a societally acknowledged right to have rights. Third, I examine the challenges posed by the modern phenomenon of poverty to the idea of right and the latter's identification with an account of political membership. Here I consider the concept of rightlessness that Hegel associates with modern poverty, how it calls into question the rights introduced by civil society, and how it calls forth a correction that further develops the principle of civil society itself. Fourth, I examine his conception of the corporation, noting how it represents a response to rightlessness, and one that contributes to the Philosopby of Right's program of realising the concept of right generally. Here I consider the relationship of the concept of right to a modern notion of ethical life, focusing on how both right and rightsconsonant with a reflexive understanding of the right to have rights - find proper realisation in the activity of individuals attending to the conditions of their sociation and of membership itself. I conclude with some brief remarks comparing Hegel's unique conception of membership rights to that of Arendt.

\section{I}

The notion that Hegel might espouse a conception of rights focused on membership in a particular community is, to be sure, contestable. For one thing, his Philosophy of Right appears to proceed from an ahistorical, 'essentialist' view of human nature. Indeed, his political thought is based on the principle of 


\section{Hegel, Human Rights, and Political Membership}

autonomous personality and a general human capacity for reflexivity, something he deems 'inherent in the essence of every man' (Hegel 1985: 75). Yet in espousing this view, Hegel is not in fact advocating an ahistorical conception of rights, nor is he affirming the prepolitical notion of rights associated with the modern natural law tradition. Such a view is precluded by his account of autonomous personality itself, which is conceived in decidedly non-naturalistic terms. Personality expresses the concept of self-determination, and selfdetermination is understood in opposition to the heteronomous constraints Hegel associates with naturalism. 'The real fact is that the whole law and its every article are based on free personality alone-on self-determination or autonomy, which is the very contrary of determination by nature' (EM §502).

In addition, Hegel asserts that the very idea of autonomous personality presupposes and demands articulation in an existing system of law. Hegel construes autonomy intersubjectively, as selfhood in otherness, or Bei-sich-selbstsein. A comprehensive account of achieved intersubjectivity depends on establishing a legal-political community juridically committed to principles of respect and reciprocity. ${ }^{3}$ On the one hand, autonomous personality depends on a social order that recognises and supports that autonomy. Conversely, that order itself depends on individuals who recognize its authority and act accordingly. Only in a lawfully ordered community is the individual 'recognised and treated as a rational being, as free, as a person; and the individual, on his side, makes himself worthy of this recognition by overcoming the natural state of his selfconsciousness and obeying a universal, the will that is its essence and actuality, the law; he behaves, therefore, towards others in a manner that is universally valid, recognising them—as he wishes others to recognise him-as free, as persons' (EM §432). It is no coincidence that Hegel construes the principle of autonomous personality in terms of a legal imperative: it is a commandment of right that one 'be a person and respect others as persons' (PR §36). Hegel may proceed from the seemingly abstract notion of autonomous personality, but a proper account of the person itself depends on a developed system of legal relations.

The point is also central to Hegel's concept of right itself. In line with the modern natural law tradition, Hegel understands right as a normative principle, one based on the principle of freedom and the free will. Indeed, for Hegel right is the idea of freedom itself. But an idea on his view is not an abstract principle contraposed to conditions of institutional embodiment. In line with his general conceptual realism, he maintains that an idea denotes a concept conjoined with its existence - an understanding consonant as well with a view of freedom as selfhood in otherness. As the idea of freedom, right itself is nothing but freedom under the conditions of its actualization; it is indeed the 'existence of the free will' (Dasein des freien Willens) (PR §29). In its capacity as a principle of freedom, right is a general normative principle. But in that capacity it is also a principle of legal 


\section{Andrew Buchwalter}

positivism, one tied to a legal system committed to its institutionalization and enforcement. Right for Hegel is the 'realm of actualized freedom', articulated in an existing system of positive law. A developed legal system is the domain in which 'freedom attains its supreme right' (PR §258) and 'in which alone right has its actuality' (EM §502).

In fashioning an embodied account of right, Hegel demonstrates his distinctive relationship to the natural right tradition. To the extent that that tradition evinces an abstract prepolitical ahistoricism, he is opposed, proposing instead that natural law 'be replaced with the designation philosophical doctrine of right' (NRPS §2). Directed to the 'idea' of that under consideration (the concept joined with its realisation), a philosophical doctrine of right affirms that right is intelligible only within the framework of developed social and political institutions (PR \$1). Elaboration of the idea of right is itself exeundum esse e statu naturae (VRP 1: 239f). And lest there be any doubt about his distance from the natural right tradition, Hegel even suggests that the term right itself is inadequate to the requirements for institutional embodiment. While sometimes calling his practical philosophy a Philosophy of Right, he elsewhere, in his philosophical system, employs the title Theory of Objective Spirit. It is this account of spirit objectified that reflects the distinctiveness in Hegel's notion of right as institutionally realised freedom.

At the same time, however, Hegel's departure from the natural right tradition should not be exaggerated. An early proponent of the method of immanent critique, Hegel maintains that the most consequential criticism of a contested position is one that confronts that position on its own terms. This expectation is no less in evidence in his reception of the tradition of natural right. Employing the dialectic of true and spurious being central to his principle of self-contradiction, Hegel criticizes the natural law doctrine because its liberal formulation conflicts not with an alien standard, but with its true self or 'nature'. Thus an analysis of individual rights in terms of their inherent concept focuses not on an individual's natural and immediate existence, but on his true being, what Hegel calls 'die Natur der Sache' (PR §57). For Hegel, a citizen is defined by a concept of autonomous personality which is realised only in developed political and cultural community. ${ }^{4}$ Hence, a defence of natural rights is likewise a defence of the principle of political community, just as a repudiation of the liberal approach to natural rights is a realisation of the concept of natural law. It is no coincidence that Hegel subtitles his Philosophy of Right Natural Law and Political Science', for the concept of natural law is meaningless on his view without an account of established political institutions. Hegel champions the idea of Objective Spirit over that of Natural Right, not because he opposes the principle of the latter, but because that principle only finds expression in a system of ethical life.

The point may be made as well by noting how appeal to communal membership itself reaffirms elements of the tradition of natural right. For Hegel, 
a proper account of communal membership depends on a self-awareness (Selbstgefuib) on the part of members of their status as members (PR §147). As Hegel says of political community generally, "ii]t is the self-awareness of individuals which constitutes the actuality of the state' (PR §265A). Proper to membership is an appreciation of oneself as a member of such community. Such self-awareness is, however, no mere acknowledgement of the norms, practices, and traditions of a particular community. Membership also involves, if in differing degrees, its acceptance and endorsement. Especially in an account of a polity, membership involves the capacity to affirm the validity of the norms and practices operative in a particular community. Such norms and practices are not simply to be obeyed but must 'have their assent, recognition, or even justification in ... heart, sentiment, conscience, intelligence, etc.' (EM \$503). For Hegel, the capacity for cognitive affirmation - it has been termed 'reflective acceptability ${ }^{5}$ — is understood by means of the language of rights. A full account of membership rests on a 'right of insight', which itself expresses the right of subjectivity central to modern accounts of freedom. 'The right to recognize nothing that I do not perceive as rational is the highest right of the subject' (PR §132). ${ }^{6}$

Hegel claims that rights are not abstract normative principles but depend on conditions for membership in existing institutional settings. It is for this reason that he supplants a Theory of Right with a Doctrine of Objective Spirit. Yet the appeal to particular communities and institutions does not entail abrogation of conception of rights. Not only is membership in a political community a condition for realizing rights, a proper account of communal membership itself entails affirmation of subjective rights and the right of subjectivity itself. Indeed, basic to the idea of Objective Spirit-where spirit for Hegel is understood as the conjunction of substance and subjectivity ${ }^{7}$ - is the ontological dependence of a communal substance on the experience of subjective reflection. Hegel construes his philosophy of right as a theory at once of natural law and positive political science. The 'interpenetration' (PR $\$ 1 \mathrm{~A}$ ) of these two approaches is not only central to but constitutive of the idea of Objective Spirit. ${ }^{8}$

\section{II}

In asserting that the meaning and reality of rights are linked to conditions of social membership, Hegel does not hold that any type of communal membership is acceptable. Needed rather is a community that can properly accommodate the requirements of an account of rights. Historically, Hegel claims that such requirements were at least minimally met with modern society and, in particular, modern civil society. Expressive of that 'system of all-round interdependence' (PR §183) diagnosed as well by theorists of political economy, modern civil 


\section{Andrew Buchwalter}

society provides, on multiple counts, the conditions for a concrete realisation and embodiment of a system of right.

First, civil society permits and fosters affirmation of a genuine account of human rights. Although critical of cosmopolitanism (PR §209), Hegel is not opposed to the concept of universal human rights. His position is rather that that concept cannot be asserted abstractly, but must be embodied in circumstances that accommodate and do justice to it. Historically, such concrete validation first occurred in modern civil society (PR §209). Previously, individuals may have been able to claim rights in virtue of particular status considerations, e.g., class, familial or ethnic background, social standing, or gender. In modern society, however, Hegel claims that the individual is now recognised, at least in principle, simply as such, in virtue of his/her very humanity (PR $\$ 124 \mathrm{R})$. Inasmuch as a system of commercial exchange best functions only to the degree that individuals, for better or worse, are now valued simply for their economically and quantitatively relevant contributions, irrespective of other status considerations, civil society permits the realisation of right as a universal principle, indeed as a uniform principle of humanity. It is not coincidental that Hegel famously advanced his claim about the universality of rights only on his discussion of civil society, for here 'I am apprehended as a universal person in which all are identical. A human being counts as such because he is a human being, not because he is Jew, Catholic, Protestant, German, Italian, etc.' (PR §209, emphasis added). Modern civil society supplies the conditions for the realisation of a notion of right wherein 'the individual as such has an infinite value', and in the sense that freedom constitutes the 'actuality of human beings-not something which they have, as men, but which they are' (EM §482).

Civil society is also important for Hegel in that it clarifies the binding nature of rights. One feature of modern civil society is its compulsory character. Given the complex, differentiated, interdependent nature of modern industrial society, individuals can pursue a livelihood only as a member of that society. Civil society is 'that immense power which draws people to itself and requires them to work for it' (PR §238). Indeed, life itself depends on such membership. For a system of realised freedom, then, membership in civil society itself entails certain rights, even as those rights also entail specific duties. ' $] \mathrm{f}$ a human being is to be a member of civil society, he has rights and claims in relation to it. ... Civil society must protect its members and defend their rights, just as the individual owes a duty to the right of civil society' (PR $\$ 238 \mathrm{~A}$ ).

Civil society further clarifies what counts as rights. Revolving around particular need satisfaction, modern societies give special place to 'negative' rights, those guaranteeing 'the undisturbed security of persons and property' (PR \$230). The system of justice institutionalized with civil society secures recognition for the principle Hegel associates with the abstract right of persons: 'not to violate (verletzen) personality and what ensues from personality' (PR §38). 


\section{Hegel, Human Rights, and Political Membership}

For Hegel, civil society is also expected to secure certain 'positive' rights, those enabling individuals to realise themselves and the freedoms civil society is presumed to actualize (NRPS \$118). Given that the livelihood and indeed the very existence of individuals is dependent on membership in civil society, society in turn has an obligation to provide the resources-e.g., subsistence, health, education, housing-enabling individuals to function effectively as members of society. The system of interdependence constituting civil society is such that 'the livelihood and welfare of individuals should be secured-i.e., that particular welfare should be treated as a right and duly actualized' (PR §230). Moreover, given that the right to life_-that which is 'absolutely essential' (NRPS §118)—is presupposed in the protection of rights of person and property, Hegel assigns a measure of priority to positive rights.

In addition, civil society gives rise to political rights, those enabling individuals to participate in collective efforts to define and shape the conditions of their shared existence. Such rights, to be sure, are fully articulated not in civil society itself, but in the state or political community proper. Yet the idea of political rights is entailed as well by requirements for full membership opportunities established with civil society. They are entailed as well by a full account of the reciprocity of rights and duties articulated by civil society. And they are entailed by the account of the complex and wide-ranging intermediation of individual and community facilitated through civil society.

Certainly Hegel does not affirm a right to direct participation in public affairs. He also does not allow for universal suffrage, preferring instead a mode of political representation based on membership in intermediate associations, subpolitical bodies, municipalities, and community based organizations (PR $\S 308 f)$. Yet far from militating against a notion of public autonomy on the part of the wider populace, participation in such entities can serve to facilitate it. Not only does membership in such bodies facilitate representation in modern societies, whose size and complexity have rendered all but impossible meaningful direct participation on the part of individuals in the affairs of state; citizen involvement in intermediate associations is a central factor in the very 'constitution' of a polity, itself based on the intermediation of objective institutional structures and subjective dispositions of individuals. In addition, Hegel maintains that governance of communities, intermediate associations, and subpolitical entities - many of which are already present in civil society-is itself linked to participatory rights. 'This is the point of view of right, that individuals have the right to administer their resources' (NRPS §141).

Civil society is distinctive not just in that in articulates the three central rights attendant on social membership. It also gives voice to a meta-right, what Hegel calls the 'absolute right' (VPRHe: 127). Right on this account denotes not simply the possession of specific rights, but the general recognition, by those directly affected and by the community as a whole, that members of society are 


\section{Andrew Buchwalter}

entitled to rights and their status as bearers of rights. This is indeed 'the right to have rights' (VPRHe: 127), ${ }^{10}$ and it is uniquely facilitated by civil society. Predicated as it is on the comprehensive mediation of individual and community, civil society provides the institutional basis to recognise general claims to right. For one thing, modern civil society underwrites the idea of a realised constitutional order, understood as a promulgated system of law applicable to society as a whole and committed to the dignity and equal treatment of each and every member of society. In addition, it furnishes the conditions for what Richard Rorty has termed a 'human rights culture, ${ }^{11}$ one in which individuals are recognised as entitled to rights and the protections they afford. Not only does civil society nurture in individuals an understanding of themselves as holders of rights that are to be respected and honoured; through its system of wide-ranging interdependence, it provides the framework for a community in which individuals appreciate that support for the rights of others and the institutions providing such support is intertwined with their own rights and wellbeing. Civil society 'gives right an existence [Dasein] in which it is universally recognized, known and willed, and in which, through the mediation of this quality of being known and willed, its validity and objective actuality' (PR §209). In terms of both institutional and cognitive requirements, civil society concretizes a right to have rights: it represents a social order in which individuals are recognised, by themselves and others, as subjects possessing rights (and corresponding duties).

\section{III}

To say that modern civil society provides the framework for a realised account of human rights is, to be sure, not to say that it itself represents the full realisation of such rights. Hegel's claim is rather that modern civil society supplies only a 'formal' account of universal human rights (EM §529), one that in reality does not acknowledge the full catalogue of rights it introduces, does not recognise all its members as rights holders, and does not accommodate realisation of a genuine human rights community. Indeed, as regards its actual functioning, civil society gives rise to a host of pathologies that not only fail to affirm full realisation of human rights but contribute to their denial. Central here is the problem of poverty, deemed by Hegel a structural feature and inevitable byproduct of the operation of market societies (VPRHe: 193). In the present context, poverty is especially significant, as it makes manifest the connection between civil society and the phenomenon of rightlessness (Recbtlosigkeit) that for Hegel is intertwined with modern social life.

In this section, I detail the connection Hegel draws between civil society and rightlessness, noting how the former disenfranchises its members even as it 


\section{Hegel, Human Rights, and Political Membership}

enfranchises them. ${ }^{12}$ Appreciation of Hegel's position on this matter clarifies what he sees as the challenges that confront establishing a human rights community under modern conditions. It clarifies as well his conception of a right to membership, one properly fashioned in conjunction with an effort to come to terms with modern poverty and the experience of rightlessness it entails.

Hegel's account of poverty in modern societies is well known. Propelled by desires on the part of individuals to maximize wealth, market societies give rise to boom-bust cycles where overproduction inevitably leads to layoffs and unemployment. In this way, modern societies engender an impoverished underclass, one that acquires a measure of permanence, since, deprived of economic resources and no longer able to draw support from the extended economic family structure of traditional societies, the poor are restricted in the mobility and opportunities needed to acquire skills to (re)gain a place in the economic life of society (PR §241). But Hegel's understanding of the rabble (Pöbel), as he terms this underclass, is focused first and foremost not on material deprivation. His attention above all is to poverty as a psychological phenomenon, one focused on a mentality of alienation and degradation. For one thing, the modern poor exhibit a lack of self-respect and self-esteem. Not only does the loss of work deprive individuals of the sense of self-reliance central to the membership ethos of modern societies, the poor are also conscious that they lack the social recognition central to a community predicated on performance and the marketability of individual effort. Moreover, to the degree that the poor appreciate their lack of social recognition, they in turn withdraw their own recognition of society, not only through envy and resentment, and not only through anger directed at the wealthy, but in an adversarial relation to society as a whole, be it in rejection of work and the achievement principle or in opposition to the social order itself.

As regards the concept of right, several observations are in order. To begin with, poverty tendentially deprives individuals of the rights they putatively enjoy as members of modern societies. Poverty calls into question claims to positive rights: well-being, work, health, subsistence, as well as life itself. In addition, poverty calls into question negative rights, those protecting individuals against violations of person and property. A right protecting property has little value for those without the means to obtain and possess goods. Moreover, inasmuch as property, on Hegel's account, is a condition for personhood and the self-externalization it requires, the inability to own and acquire property questions the right of personhood itself. Finally, the poor are deprived of political rights. Without necessary capital and resources (education, skills, clothing, health), the poor are effectively barred from participating in public fora for the collective shaping of social and political life.

The loss of rights associated with poverty also speaks to the diminished status of the poor as members of modern societies. Inasmuch as they are effectively deprived of liberty, welfare, and political rights, the poor are of course 


\section{Andrew Buchwalter}

unable to enjoy the benefits associated with membership in a society for which the ability to claim and exercise such rights is central to individual functioning and well-being. Deprived of material resources, the poor also see themselves as deprived of membership rights in a society culturally defined by a commitment to principles of economic self-reliance. In addition, the lack of rights serves to deprive the poor of their very status as social members. In civil society, individuals are recognised as members in virtue of the rights they possess, rights ensured by civil society itself. Inasmuch as the poor lack rights, they are thus not recognised as fully-fledged social members, a state of affairs that leads to their further marginalization. Moreover, given that in civil society rights are connected not only to personhood but humanity itself, poverty serves to depersonalize and dehumanize the poor, with the discrimination and abuse that can entail. Nor is this an attitude of misrecognition emanating simply from the social order itself. Given Hegel's intersubjective account of self-identity, the poor increasingly internalize such attitudes, participating thereby in their own disenfranchisement. In multiple respects, poverty contributes both to the rightlessness and the 'feeling of rightlessness' (Gefühl der Rechtlosigkeit) of the poor (VPRHo \$244).

It is not Hegel's contention that the poor are wholly without rights; at issue is not an absolute deprivation. Nor is he suggesting that the poor are wholly deprived of membership in an organized political community; unlike Arendt, his claim is not that rightlessness takes the form of statelessness (Cf. Arendt 1973: 177). His point is rather that the nature of modern poverty is such that the poor are not in fact recognised-by themselves or others-as possessing the rights to which they are nonetheless entitled (PR §244A). The poor suffer from the 'non-recognition of right' (VPRHe: 196). Indeed, the rabble mentality specific to the modern poor consists in just the awareness of a 'discrepancy' between formally held and actually available rights (VPRHe: 195). The rabble phenomenon articulates 'the consciousness of rightlessness under the presupposition of right' (VPRHo \$244). ${ }^{13}$ The specific sense of alienation experienced by the poor consists in their being regarded, by themselves and others, as non-members of a society to which they nonetheless belong. For the poor, social membership takes the form of membership denied. ${ }^{14}$

This point bears on the adversarial attitude displayed by the poor in response to their disenfranchisement. This attitude assumes, inter alia, forms of increasingly lawless behaviour: made to feel rightless by the modern social order, the poor may 'make themselves rightless', placing themselves outside the law (VPRHo \$244). In its most pronounced form, this attitude finds expression in active resistance to the legal-political order itself. Triggered by the 'injustice' (Unrecht) perpetrated on the poor by modern society (PR §244R), this response itself assumes the 'form of right' (VRP 4, 609f). ${ }^{15}$ As such, it bears affinities to the 'right of distress' (Notrecht) that Hegel elsewhere formulates in response to specific 
cases of acute socio-economic need (PR §127). Here, however, 'distress' denotes not a particular or 'momentary' occurrence (VPRHe: 196), but a systemic feature of the social order itself, with the result that right itself now finds expression in resistance to that order; at issue is indeed a right to rebel (Recht zum Aufstand).

Importantly, however, Hegel is not calling for a total elimination or removal of the existing social order-one point demarcating his position on the rabble from that articulated by Marx with regard to the proletariat. ${ }^{16}$ Consonant with the 'inner indignation' illustrative of the adversarial attitude of the poor (PR §244R), a right of resistance for Hegel is more reformative than insurrectionary: it is to confront the social order with its own implicit norms and standards. Resistance seeks to address 'the contradiction between what is promoted and the situation in which individuals find themselves' (VRP 4: 477). In this respect, a right of resistance is part of a practical philosophy conceived as an effort to actualize and further realise an existing and already promulgated conception of right. ${ }^{17}$

To say that resistance is directed more to reform than revolution is, to be sure, not to see it as any less demanding. On the contrary, reform poses no less a challenge. Central to Hegel's analysis of the rabble is the experience not just of the poor but also the wealthy, those comprising whom he calls the 'rich rabble' (VPRHo §244). These are individuals whose avarice contributes to broader material inequities and whose insouciant and disdainful attitude dehumanizes the poor. Moreover, the wealthy contribute significantly to the state of rightlessness associated with modern poverty, pauperization, and the general social impoverishment Hegel terms a 'loss of ethicality' (PR §184). Through their wealth, the rich not only subject the poor to their will and caprice; they easily bend and circumvent the law in order to achieve their own ends, supplanting thereby right with might (VPRHo §244). Moreover, through their 'arrogance' (Hocbmut) (PR §253R) toward the poor, the rich undermine the relations of mutuality central to a legal order based on a far-reaching system of interdependence, including the co-dependency of rights and duties. In their own display of the rabble phenomenon (Pobelhäftigkeit), the wealthy also challenge the principles of right and ethicality implicit in civil society.

Against this backdrop, modes of social resistance that appeal to a discrepancy between social norms and actual practices may seem uncompelling. Given that the wealthy see themselves as benefitting from disparities in wealth and power that contribute to the problems in question, they have little obvious interest in addressing those problems. Indeed, they would likely meet resistance with that of their own. For this and other reasons, Hegel asserts '[i]t is precisely the excess of wealth that renders civil society too poor to address an excess of rabble' (VRP 4: 611). ${ }^{18}$

Yet if efforts at social reform may seem implausible, they are still warranted. This is so because the wealthy suffer from a 'misapprehension' (Irrtum) about 


\section{Andrew Buchwalter}

their interests and the nature of the society to which they belong (PR §181A). As a matter of principle, civil society is a domain which gives full rein to every individual's pursuit of his or her particular sense of well-being (PR §182). Yet however precisely that principle is understood, it is one that, for Hegel, must be supplemented with another one: self-chosen ends cannot be satisfied without reference to others and to one's membership in a society understood as a 'system of all-round interdependence' (PR §183). Central to the concept of civil society is that individual subsistence and well-being are inextricably intertwined with the subsistence and well-being of others. Central as well is that individual rights are not fully secured without corresponding duties to others and the social order itself. Further, given that civil society does establish a system of all-round interdependence (allseitiger Abhängigkeit), individual well-being is fully achievable through attitudes, not of arrogance, domination, lawlessness or other forms of one-sided dependence, but of those fostering respect, cooperation, and mutuality. ${ }^{19}$ On a proper apprehension of their interests, then, the rich themselves benefit from a system of right committed to the integration and enfranchisement of all members of society. For Hegel, the rich as well benefit from insight into a 'higher ethical necessity' (VRP 4: 479).

Hegel is well aware of the challenges confronting any transformation of consciousness on the part of members of civil society. Still, it is his view that rectifying the rightlessness endemic to a society gripped by significant poverty can properly be achieved only through such transformation. In this respect, efforts that call attention to the discrepancy between the avowed claims of a social order and its actual conditions are of importance. Moreover, given that a legitimate legal order and, indeed, a properly developed account of right are themselves achieved only in a rights culture comprised of individuals attentive to and supportive of the conditions of their sociality, an effective response to the problem of poverty entails an important step in the realisation of the concept of right itself. Here we perceive the systematic role played by the phenomenon of poverty in the justificatory program of the Philosophy of Right. Hegel adumbrates this point in his account of the corporation, to which we now turn.

\section{IV}

For Hegel, there are no easy answers to the problem of modern poverty. One partial solution, however, lies in the idea of the corporation, voluntary work-related cooperatives that hark back to the Medieval and early modern guild system and find attenuated reaffirmation today in labour unions, professional associations, and trade organizations. ${ }^{20}$ There are many features to Hegel's 'corporative' solution. Generally speaking, though, corporative membership addresses both 


\section{Hegel, Human Rights, and Political Membership}

the material and psychological problems associated with modern poverty. For one thing, corporations counteract the ill-effects of market societies by furnishing assistance to those of its members made indigent by market forces. They do so in part by providing direct material assistance to those in need or distress. They do so as well through various job training and placement programs meant to (re)integrate its members into the economic life of society (PR $\S \S 255 \mathrm{f}$ ). In addition, corporate membership serves to counter the humiliation and lack of self-respect triggered by pervasive poverty and chronic unemployment. Inasmuch as membership in a specific work-related cooperative valorises skills and talents the individual possesses by virtue of that membership, it reinforces the particular, 'qualitative' sense of self-worth, esteem or honour (Ehre) ignored and undermined in the system of recognition associated with the modern legal system - that focusing on the abstract and quantitatively uniform right of all to pursue their individual selfinterest. In the corporation, the individual is recognised as 'somebody' (PR §253). Furthermore, corporate membership, in inculcating a sense of commonality, not only renders individuals — the 'arrogant' wealthy included - more apt to contribute to the welfare of the whole, but nurtures the type of consciousness directed to the shared responsibilities obscured in a system of self-seeking, 'atomistic' individualism. And inasmuch as corporate members themselves contribute to eliminating the pathologies of modern commercial life, their actions circumvent 'statist' solutions which, imposed exogenously, reinforce the 'humiliating' dependency illustrative of the problems in question (PR §245).

For present purpose, corporate membership is important in that it clarifies and further realises the concept of right. In Hegel's understanding, the corporation affirms and publicly ratifies the concept of human dignity attached to a modern concept of right, one for which human beings are recognised as such, irrespective of status considerations. As noted, this is a principle implicit in the concept of civil society, but is effectively undermined by the phenomenon of poverty, which dehumanizes individuals, denying them a sense of self-worth while reintroducing in new ways the status hierarchies that civil society was presumed to eliminate. Hegel claims that this state of affairs changes, however, in corporative existence. As a member of a corporation, an individual is esteemed not in terms 'of the external manifestations of success ...' (PR §253A), but simply in virtue of membership in an organization for which the value of the trade, profession, or occupation is presumed. Rich or poor, individuals are now recognised, and in a way possessing 'genuine effect' (rechte Wirksamkeit) in the thinking of others, simply 'as such' and for 'what one is' (VPRHo §253). Such recognition, to be sure, is not realised society-wide, but for members of a corporation notions of equal worth and 'equality' now become core principles of inter-personal valuation and constitutive features of the social order itself (VPRHo §253). 


\section{Andrew Buchwalter}

The corporation is important further in that it concretely affirms a positive right to subsistence and well-being generally. This is a right formally attached to the general idea of civil society but, owing to the phenomenon of poverty, finds only limited acknowledgement in modern societies themselves. Several points are here in order. First, inasmuch as corporative entities recognise individuals in terms of the talents, skills, and capacities specific to membership in a particular occupational association, it attends to individuals in terms of their particular needs and interests rather than simply their abstract humanity. Second, the selfinterest of particular individuals is now construed not simply as such but in terms of its value to the corporation. Accordingly, particular interests lose their merely subjective and contingent status and acquire 'objectivity' and 'general validity' as well. Here the individual is treated in his particularity not as individual but as universal' (VPRHe: 205). Moreover, inasmuch as individual interests are now integrated into the well-being of the corporative body, the latter in turn has the responsibility to ensure that individuals have the resources to contribute to the corporation and the shared well-being of corporate members-resources that can include education, health, care, subsistence and all that ensuring the life and livelihood of members. Part and parcel of corporate membership is the 'securing of subsistence' of corporate members. Assistance so guaranteed (ein Gesichertes) (VPRHe: 202) counts for Hegel as a right-indeed, a 'right to assistance' (VPRHo §253). Such a right is nominally a component of membership in civil society as such, yet only in the corporation is it 'recognised, guaranteed, and at the same time raised to a conscious activity for a common end' (PR §254). In conjoining individual and community, the corporation thus provides public acknowledgment and support for a right to the subsistence and well-being of individuals. In the corporation, the internally reflected particularity of need and satisfaction and abstract legal [rechtlichen] universality are inwardly united in such a way that the particular welfare $(W o b D)$ is present as a right and is actualized within this union' (PR §255).

The corporation also articulates the ethical (sittliche) assumptions that underlie a realised system of rights. Such a system is not self-standing but presupposes individuals cognitively and volitionally disposed to support such a system. Such civic sentiment, to be sure, is implied by the very idea of civil society, which, forged in the wide-ranging interdependence of universal and particular, provides the framework in which individuals can make the collective welfare and the conditions of their sociation an explicit object of consciousness and will. Under unfettered market conditions, however, this conjunction remains an 'unconscious necessity' (PR $\S 255 \mathrm{~A}$ ), whereby the well-being of the whole remains the incidental by-product of individuals pursuing their private interests. This changes, however, with the corporation, where the 'internal reflexivity' inherent in modern notions of need and satisfaction are also explicitly intertwined 


\section{Hegel, Human Rights, and Political Membership}

with the norms and welfare of the community as a whole. In the corporation (wherein 'the ethical (Sittliche) makes its return in civil society' [VPRHe, 202]), communal well-being becomes an object of the 'conscious activity' (PR §254) of corporate members, who as a matter of ordinary practice attend to the connection of their own welfare and that of community. ${ }^{21}$

Nor is this consciousness merely a reflective sort, one that brings to light a pre-existing commonality. It is constitutive as well. For Hegel, a system of right finds full realisation in the conscious acknowledgement on the part of its members of their mutual dependency, reflected above all in an appreciation of the co-implication of rights and duties. To the degree that corporate membership articulates this consciousness, it also realises the concept of right itself. This concept is 'actualized' (PR \$255) in the consciousness of the co-dependency of an individual's own well-being and that of the corporate community.

Corporate membership thus further elaborates and clarifies the idea of right itself. Right for Hegel is the existence of the free will. But freedom is realised not simply through its objectification in existing practices and institutions. It requires as well that individual know and understand themselves as free. Realised right is 'self-conscious freedom' (PR §30). Self-conscious freedom, however, is not a narrowly cognitive phenomenon; it is a form of practical agency as well. Rooted in an understanding of freedom as selfhood in otherness, self-conscious freedom is intertwined with the modes of action needed to ensure that individuals can locate themselves in fact in the conditions of their social existence. A system of realised freedom is shaped in the 'knowledge and activity' of affected individuals; it is not fully possible without 'conscious agency' (PR §260). Since realised freedom is the idea of right, a political community self-consciously devoted to realising freedom, inasmuch as that represents the fullest form of such realisation, is also the most concrete expression of right itself. ${ }^{22}$ In a concrete articulation of the principle of the reflexivity germinated in civil society, right for Hegel finds quintessential expression in a legal-political community that, qua 'self-related organism' (PR §259), is realised in the practice of members enacting the conditions of their commonality.

So understood, Hegel's elaboration of the conception of right is centrally linked to the poverty manifest in civil society. Owing to the phenomenon of poverty and the social pathologies with which it is connected, civil society in its ramified expression takes the form of a state of general and pervasive rightlessness. Accordingly, an account of the concrete realisation of freedom central to the validation of the principle of right cannot remain a theoretical exercise. If the principle of right is to attain concrete realisation, social reality, in the form of the agency of social members, must itself cure the problem. The rightlessness endemic to social relations in civil society mandates the transformative activity of individuals who through their agency explicitly establish relations of right as the ruling principle of 


\section{Andrew Buchwalter}

their sociation. In the face of poverty and the rightlessness it spawns, realised right now is part and parcel of the activity of social agents vindicating for themselves principles of social justice, forging thereby the conditions of their sociality. Indeed, the two sides to the process-rectifying injustice (Unrecht) and restoring right (Recht) — go hand in hand: establishing relations of reciprocity entailed by the idea of realised freedom itself serves to defuse and disperse the forms of misrecognition and one-sided dependence associated with social impoverishment.

The phenomenon of poverty thus occasions, as Dieter Henrich has argued, articulation of a 'higher conception of right'. ${ }^{23}$ In the face of the social injustice associated with modern poverty, an account of right as realised freedom can no longer take the form of a theoretical reflection on the forms of right. Instead, right now becomes a practical activity in which members of a political community establish and re-establish the conditions of their sociation. In response to the problem of poverty right now becomes a concept of modern ethicality (Sittlichkeit), understood as the explicit activity of members of a political community clarifying the conditions of membership itself. In corporate existence, defined by Hegel as 'knowing and thinking ethical life' (PR §255A), ethicality is a self-reflexive phenomenon, one where members of a community, in enacting modes of mutuality, articulate the principle of right itself. The corporation gives expression to a notion of ethicality understood as 'right-constituting praxis', ${ }^{24}$ and right, as the self-consciousness of freedom in the world, is the consummate expression of ethicality. Traversing a course from a mere 'determination of concepts' to 'a more advanced formation', Hegel proffers a concept of right understood as a social reality that gives itself the shape (Gestalt) of right (PR §32).

A similar point can be made with regard to the concept of rights themselves. Against the backdrop of the rightlessness associated with poverty, rights cannot be understood simply as entitlements individuals are deemed to possess. Instead, they must also be understood as practical or political principles. For a Philosophy of Right committed to the actualization of freedom in the world, an account of rights also represents the capacity of agents, individually and in concert, to forge and maintain the conditions of a just legal community. As noted, Hegel claims that the absolute right is the right to have rights. At issue, however, is not just the right to have rights claims recognised and honoured. Rights here also connote a reflexive principle, one acknowledging that rights must include the capacity to define the nature, meaning, and application of rights themselves. Like the conception of right itself, rights for Hegel encompass the ability of individuals, cognitively and volitionally, to attend to the conditions of their sociation. ${ }^{25}$

To be sure, Hegel is not claiming that the corporate membership itself serves to concretize definitively either a notion of right as ethicality or a politically self-reflexive notion of rights. As a final justification, it is deficient in several respects. It attends only to membership in a particular vocational entity, not 
society in general. It counts as corporate members principally trade professionals, thus excluding wage labourers and many affected by poverty. Its notion of commonality derives from the 'inherent likeness' (PR §251) of members, and thus does not accommodate the forms of societal differentiation needed to fashion as comprehensively self-reflexive understanding of right. And its notion of civic engagement is restricted to the exigencies of a particular community and not the idea of community itself. In this regard, proper vindication of the principle of right mandates transition from civil society to a proper account of a polity, one that attends to society as a whole, accommodates political differentiation, and understands community explicitly as the self-consciousness of community itself.

At the same time, however, this transition should not be understood as an 'abstract negation', a simple repudiation of the structure of corporate community. Instead, the concept of right and the notion of membership rights eventually fashioned in a polity simply elaborate on what is first broached with civil society and the corporation. Central to the idea of right as articulated in a genuine political community is the principle of the equal worth of citizens, the concept that rights must be understood as conditions for the actual well-being of individuals rather than mere formal possibilities, that rights include the capacity to reflect on the conditions for rights themselves, and that realised right takes the form of a political community committed to realizing the conditions of community itself. Yet development of these notions itself represents an answer to the forms of injustice and rightlessness Hegel saw as endemic to civil society and for which corporative community represents a crucial, if initial, response. ${ }^{26}$

Hegel's position anticipates that sketched by Jürgen Habermas in his essay 'The Concept of Human Dignity and the Realistic Utopia of Human Rights'. Suggestively, Habermas also indicates how recognition of human rights and the concept of human dignity on which it is based emerged from the notion of social honour central to the corporative ethos. In addition, he notes the centrality of 'membership in an organized community in space and time' (Habermas 2012: 70) for a realised account of human rights. He details as well how a realised system of human rights often emerges as a response to 'the historical experience of humiliation and debasement' (Habermas 2012: 73). He further contends that establishing and maintaining a system of right depends on a citizenry nourished in a republican commitment to the public good (Habermas 2012: 71).

There are, however, several differences in the two positions. First, whereas Habermas understands corporate existence as a historical way-station on the road to general concept of human dignity, Hegel holds that membership in subpolitical and other intermediate associations remains, given the scope and scale of modern societies, an ongoing condition for securing and maintaining respect for human dignity. Second, whereas Habermas understands the experience of debasement and 


\section{Andrew Buchwalter}

humiliation (for Hegel, the misrecognition associated with poverty and pauperization) as features of a social and political history that supplements a conceptual account of the development and legal instantiation of a notion of human worth and dignity (Habermas 2012: 73), Hegel—for whom social bifurcation (Entzweiung) is famously the wellspring of philosophy itself ${ }^{27}$ —integrated such history directly into the conceptual account. Third, Hegel locates republican support for the idea of human rights less in a self-legislating democratic citizenry than in a notion of ethical life characterized by a communal and recognitively-based commitment on the part of individuals to establish and maintain the conditions of their commonality in the face of challenges confronting those conditions.

\section{V}

Like Arendt, Hegel maintains that rights are linked to membership in a social order supportive of those rights. He differs, though, in the manner in which membership concretizes principles of right and in what they both term 'a right to have rights'. Though not without its ambiguities, Arendt's position is that membership serves to embody a pre-existing understanding of what counts as rights. Such is in keeping with a notion of right to have rights 'ontologically rooted' in the conditions for the mutual self-disclosure of individuals entailed by an account of human natality (Arendt 1958: 246). By contrast, membership in a historically existent community plays a greater role in shaping Hegel's understanding of the nature and meaning of rights. In particular, he claims that the emergence of modern civil society is decisive for realising a notion of right to have rights. Civil society itself creates the conditions for the establishment and concrete recognition of the idea of universal human rights itself. It also details the specific form such rights may take, affirming (negative) liberty rights and (positive) social rights as well as the political rights favoured by Arendt. In addition, it also undergirds an account where possession of rights is intertwined with the institutional and cultural understanding that members are entitled to have those rights recognised.

Hegel, of course, is aware of how civil society subverts realisation of the rights it introduces. On his view, the phenomenon of modern poverty contributes to a general situation of rightlessness that disenfranchises large numbers of individuals and undermines the general conditions for social membership. In this respect, Hegel anticipates the position of Arendt, whose membership-based account of rights is fashioned in conjunction with a depiction of the forms of rightlessness experienced by so many individuals in modern societies. Yet differences in the two positions are noteworthy. For Arendt, rightlessness denotes the full absence of membership rights, a state of affairs no doubt accounting for her normative appeal to a concept of the human condition and to a presupposed 
notion of human agency. ${ }^{28}$ By contrast, rightlessness for Hegel denotes a state of affairs in which members of a society are denied the rights to which they are nonetheless formally entitled.

Appreciation of this point is important because it reflects both Hegel's distinctive response to the phenomenon of rightlessness and the account of right as realised freedom he fashions as a result. Response to the phenomenon rightlessness requires, on his view, an internal transformation and self-rectification of an existing social order. Here the mediation between individual and community already introduced with civil society is reshaped so that a common welfare that is initially the incidental by-product of individuals pursuing their private interest now becomes the explicit end of individual agency itself. But the response also clarifies Hegel's concept of right as realised freedom, which is conceived reflexively, in terms of effort on the part of individuals, singly and in concert, to define, establish, and maintain the conditions of their shared commonality. For Hegel, right as a right to political membership quintessentially takes the form of the activity of community members forging the conditions of membership itself. Little else than a reflexive rendering of a right to have rights is to be expected from a thinker whose concept of right itself is detailed and validated in the selfconscious realisation of spirit in the world. ${ }^{29}$

\section{Andrew Buchwalter \\ University of North Florida abuchwal@unf.edu}

\section{Notes}

\footnotetext{
${ }^{1}$ Abbreviations: EM: Hegel (1971). NRPS: Hegel (1995). PR: Hegel (1991). VRP: Hegel (1973); page numbers follows volume number. VPRHe: Hegel (1983). VPRHo: Hegel (2005). ${ }^{2}$ See also the Grundlinien der Philosophie des Rechts, Hegel (1970, Vol 7, §94, handwritten notes). ${ }^{3}$ See Hinchman (1984), Smith (1989: particularly 57-97), and Charles Taylor (1985: 187-210).

${ }^{4}$ Cf. VRP 4: 109.

${ }^{5}$ Hardimon (1994: 158).

${ }^{6}$ For a discussion of these issues, albeit not directly from the perspective of political membership, see Neuhouser (2000: 248 and generally chap 7 ['The Place of Moral Subjectivity in Ethical Life']).

${ }^{7}$ Thus the definition of spirit proffered in the preface to Phenomenology of Spirit (Hegel 1977a, 14).

${ }^{8}$ For a discussion of themes addressed in this section with regard to Hegel's relationship to Marx, see Buchwalter (2012, chap 1).

9 See Vieweg (2012: 319).

${ }^{10}$ See also Hegel (1970 7 \$94, handwritten notes).
} 


\section{Andrew Buchwalter}

11 Rorty (1993).

${ }^{12}$ I have formulated elements of this analysis, especially as regards themes in global justice, in Buchwalter (2012, chap. 11). See also Buchwalter (2013, 218-221).

${ }^{13}$ Ruda (2011: 99-104) has characterized the disenfranchisement of the rabble as consisting in a 'right without right'.

14 See further Buchwalter (2012, chap 11).

${ }^{15}$ See Dieter Henrich's Introduction to VPRHe (18-21).

16 As Marx writes (2000: 81): 'in the formation of a class with radical chains, a class in civil society that is not a class of civil society, of a social group that is the dissolution of all social groups, of a sphere that has a universal character because of its universal sufferings and lays claim to no particular right, because it is the object of no particular injustice but of injustice in general. This class can no longer lay claim to a historical status, but only to a human one. It is not in a one-sided opposition to the consequences of the German political regime, it is in total opposition to its presuppositions. It is finally, a sphere that cannot emancipate itself without emancipating itself from all other spheres of society and thereby emancipating these other spheres themselves. In a word, it is the complete loss of humanity and thus can only recover itself by a complete redemption of humanity. This dissolution of society, as a particular class, is the proletariat'.

${ }^{17}$ Klaus Vieweg (2012: 328-331, 452f) is correct to reject any construal of a Hegelian right to resistance directed to the wholesale elimination or annihilation of existing civil society. However, Vieweg's language of 'reacquisition', 'restitution', or 'reestablishment' may not do full justice to the corrective or reformative dimension of a right to resistance.

18 This formulation differs from that in the 1821 published version of the Philosophy of Right, where civil society is deemed incapable of resolving its problems '[d]espite an excess of wealth' (PR §245, emphasis added).

${ }^{19}$ For an extensive discussion of these issues, see Ruda (2011: especially chap 6, 65-81).

${ }^{20}$ In Buchwalter (2013), I present Hegel's account of corporations as an element in his general view of the relationship of religion and politics..

${ }^{21}$ For a discussion of how for Hegel imbalances in market economics are to be addressed not through an 'invisible hand' but the conscious agency of an engaged corporate citizenry, see Priddat (1990, especially chap 8).

${ }^{22}$ For a discussion of Sittlichkeit als Recht (and Recht als Sittlichkeit), see Weisser-Lohmann (2010: especially chaps 7 and 8).

${ }^{23}$ Dieter Henrich, 'Einleitung des Herausgebers' (VPRHe: 21).

${ }^{24}$ Weisser-Lohmann (2010: 201).

${ }^{25}$ Hegel thus anticipates Rainer Forst's account of rights as a 'basic right to justification'. Affirming the reflexivity inherent in a basic conception of rights, Forst writes: 'the point of human rights is that persons have the basic right to live in a society where they themselves are the social and political agents who determine which rights they can claim and have to recognise'. See Forst (2012: 102). One way in which Hegel differs from Forst, however, is that he construes this reflexive account of rights in terms of a theory of ethical life, where rights take the form of a political community committed to attending to the conditions of its commonality. 


\section{Hegel, Human Rights, and Political Membership}

${ }^{26}$ In 'Constitution, Fundamental Rights, and Social Welfare in Hegel's Philosophy of Right', Ludwig Siep (2004) details Hegel's account of individual liberty and welfare rights, while also asserting that Hegel subordinates this account to one addressed to the demands of communal membership associated with a genuine polity and the ultimate ends of political life. In this paper I have challenged this view, noting that for Hegel a realized approach to rights depends on the existence of a properly developed ethical community, just as that community itself subsists in its commitment to realizing right.

27 'Dichotomy (Entryeing) is the source of the need of philosophy' (Hegel 1977b: 89). The translators render Entzweiung as 'dichotomy'; here I employ the term 'bifurcation'.

${ }^{28}$ Consider her invocation of the 'elementary grammar of political action' (Arendt 1965: 173). She also speaks of the 'elementary structure of joint enterprise as such' (172).

${ }^{29}$ Apposite here is Hegel's rejection of a distinction between reason as 'self-conscious spirit' and reason as 'present reality'.

I wish to thank Thom Brooks for inviting me to submit this essay.

\section{Bibliography}

Arendt, H. (1958), The Human Condition. Chicago: University of Chicago Press. Arendt, H. (1965), On Revolution. New York: Viking Press.

Arendt, H. (1973), The Origins of Totalitarianism. New York NY: Harcourt Brace Jovanovich.

Buchwalter, A. (2012), Dialectics, Politics, and the Contemporary Value of Hegel's Practical Philosophy. New York and Abingdon Oxon: Routledge.

Buchwalter, A. (2013), 'Religion, Civil Society, and the System of an Ethical World: Hegel on the Protestant Ethic and the Spirit of Capitalism', in A. Nuzzo (ed.), Hegel on Religion and Politics, Albany NY: SUNY Press. 213-232.

Forst, R. (2012), 'The Justification of Human Rights and the Basic Right to Justification: A Reflexive Approach', in C. Corradetti (ed.), Philosophical Dimensions of Human Rights: Some Contemporary Views. Dordrecht: Springer Verlag. 81-106.

Habermas, J. (2012), 'The Concept of Human Dignity and the Realistic Utopia of Human Rights', in C. Corradetti (ed.), Philosophical Dimensions of Human Rights: Some Contemporary Views. Dordrecht: Springer Verlag. 63-79.

Hardimon, M. O. (1994), Hegel's Social Philosophy: The Project of Reconciliation. Cambridge: Cambridge University Press.

Hegel, G. W. F. (1970), Werke in zwanæig Bänden, ed. E. Moldenhauer and K. M. Michel. Frankfurt: Suhrkamp Verlag. Hegel, G. W. F. (1971), Hegel's Philosophy of Mind. Part 3, Encyclopaedia of Philosophical Sciences, trans. W. Wallace and A. V. Miller. Oxford: Clarendon Press.

Hegel, G. W. F. (1973), Vorlesungen über Rechtsphilosophie 1818-1831, 4 vols, ed. K.-H. Ilting. Stuttgart-Bad Cannstatt: Friedrich Frommann. 


\section{Andrew Buchwalter}

Hegel, G. W. F. (1977a), Phenomenology of Spirit, trans. A. V. Miller. Oxford: Clarendon Press.

Hegel, G. W. F. (1977b), The Difference Between Fichte's and Schelling's System of Philosophy, trans. H. S. Harris and W. Cerf. Albany NY: State University of New York Press. Hegel, G. W. F. (1983), Vorlesungen über Philosophie des Rechts 1819/20, ed. D. Henrich. Frankfurt: Suhrkamp.

Hegel, G. W. F. (1985), Introduction to the Lectures on the History of Philosophy, trans. T.M. Knox and A.V. Miller. Oxford: Clarendon Press.

Hegel, G. W. F. (1991), Elements of the Philosophy of Right, ed. A. Wood, trans. H. B. Nisbet. Cambridge: Cambridge University Press.

Hegel, G. W. F. (1995), Lectures on Natural Right and Political Science: The First Philosophy of Right, Heidelberg 1817-1818 with Additions from the Lectures of 1818-1819, transcribed by P. Wannenmann, trans. J. M. Stewart and P. Hodgson. Berkeley: University of California Press.

Hegel, G. W. F. (2005), Die Philosophie des Rechts. Vorlesung von 1821/22, ed. H. Hoppe. Frankfurt: Suhrkamp Verlag.

Hinchman, L. P. (1984), 'The Origin of Human Rights. A Hegelian Perspective', The Western Political Quarterly 37(1), 7-31.

Marx, K. (2000), 'Towards a Critique of Hegel's Philosophy of Right. Introduction', in Karl Marx: Selected Writings, 2nd edition, ed. D. McLellan. Oxford: Oxford University Press. 71-82.

Neuhouser, F. (2000), Foundations of Hegel's Social Theory: Actualizing Freedom. Cambridge MA: Harvard University Press.

Priddat, B. P. (1990), Hegel als Ökonom. Berlin: Dunker \& Humblot.

Rorty, R. (1993), 'Human Rights, Rationality, and Sentimentality', in S. Shute and S. Hurley (eds.), On Human Rights: Oxford Amnesty Lectures. New York: Basic Books. 111-134.

Ruda, F. (2011), Hegels Pöbel. Eine Untersuchung der 'Grundlinien der Philosophie des Rechts'. Konstanz: Konstanz University Press.

Siep, L. (2004), 'Constitution, Fundamental Rights, and Social Welfare in Hegel's Philosophy of Right', in R. Pippin and O. Höffe (eds.), Hegel on Ethics and Politics. Cambridge: Cambridge University Press. 268-290.

Smith, S. S. (1989), Hegel's Critique of Liberalism. Rights in Context. Chicago: Chicago University Press.

Taylor, C. (1985), 'Atomism', in Philosophical Papers 2. Cambridge: Cambridge University Press. 187-210.

Vieweg, K. (2012), Das Denken der Freiheit. Hegels 'Grundlinien der Philosophie des Rechts'. Munich: Wilhelm Fink Verlag.

Weisser-Lohmann, E. (2010), Rechtsphilosophie als praktische Pbilosophie. Hegels Grundlinien der Philosophie des Rechts und die Grundlegung der praktischen Phillosophie. Munich: Wilhelm Fink Verlag. 